\title{
ANALYSIS OF MICROBIOLOGICAL INDICATORS OF FOOD EMULSIONS
}

\author{
I. Ustymenko, N. Korh, S. Teterina, G. Polischuk \\ National University of Food Technologies
}

\begin{tabular}{l}
\multicolumn{1}{c}{ Key words: } \\
Food emulsion \\
Sodium caseinate \\
Emulsifier \\
Water activity \\
Microbiological analysis \\
\hline \multicolumn{1}{c}{ Article history: } \\
Received 13.03.2018 \\
Received in revised form \\
05.04.2018 \\
Accepted 17.04.2018 \\
\hline
\end{tabular}

Corresponding author:

I. Ustymenko

E-mail:

ustymenko_ihor@ukr.net

\begin{abstract}
The article presents the results of microbiological analysis of food emulsions intended for the normalization of mixtures in milk-based products. Emulsions are provided in the process of coarse distillation emulsification at a temperature not lower than $76 \pm 2^{\circ} \mathrm{C}$ for 20 minutes with subsequent two-stage homogenization in a homogenizer-dispersant of valve type at a temperature not lower than $60^{\circ} \mathrm{C}$ and pressure on the first stage not lower than 10.0 MPa, and on the other - 2.5...3.0 MPa.

The purpose of the study is to confirm the safety of food emulsions obtained by certain treatment regimes by microbiological parameters.

As the objects of the study there were selected samples of food emulsions with mass fraction of fat from 10 to $50 \%$ immediately after receiving and during temporary storage at a temperature of $4 \pm 2^{\circ} \mathrm{C}$ for 96 hours. Refined deodorized corn oil is used as the fatty component. An emulgator-protein complex consisting of an oleophilic emulsifier "Esther Tier 2 (T-2)" and sodium caseinate were used to obtain stable emulsions with a mean diameter of fatty bands of not more than 2 microns. According to the research methodology, the total number of mesophilic, aerobic and facultative anaerobic microorganisms, yeast and mold fungi and bacteria of the coliform group were determined as indicators of microbiological safety in emulsions in the process of temporary storage.

The total number of mesophilic, aerobic and facultative anaerobic microorganisms of all samples immediately after receiving the emulsion was at the level of 1.6...4.8 $102 \mathrm{CFU} / \mathrm{g}$, which is practically three orders less than the normative value (nMAFAnM, CFU/g, not more than $2 \cdot 105$ ). The results of the study confirmed the safety of emulsions during a technologically appropriate storage before their addition to milk-based products.
\end{abstract}

DOI: $10.24263 / 2225-2924-2018-24-2-25$

\section{АНАЛІЗ МІКРОБІОЛОГІЧНИХ ПОКАЗНИКІВ ХАРЧОВИХ ЕМУЛЬСІЙ}

\author{
І.М. Устименко, Н.С. Корх, С.М. Тетеріна, Г.С. Поліщук \\ Національний університет харчових технологій
}

У статті наведено результати мікробіологічного аналізу харчових емульсій прямого типу, щзо призначені для нормалізації сумішей у технологіях мо- 
локовмісних продуктів. Емульсії передбачено одержувати в процесі грубодисперсного емульгування за температури не нижче $76 \pm 2{ }^{\circ} \mathrm{C}$ впродовж 20 хвилин з подальшою двоступеневою гомогенізачією на гомогенізаторідиспергаторі клапанного типу за температури не нижче $60^{\circ} \mathrm{C}$ і тиску на першому ступені не нижче 10,0 МПа, на другому - 2,5...3,0 МПа.

Метою дослідження є підтвердження безпечності харчових емульсій, одержуваних за визначеними режсимами оброблення, за мікробіологічними показниками.

Об'єктами дослідження обрано зразки харчової емульсій з масовою часткою жиру від 10 до 50\% відразу після отримання та під час тимчасового зберігання при температурі $4 \pm 2{ }^{\circ} \mathrm{C}$ впродовж 96 годин. Як жировий компонент застосовували рафіновану дезодоровану кукурудзяну олію. Для одержання стійких емульсій із середнім діаметром жирових кульок не більше 2 мкм використовували комплекс «емульгатор-білок», що складається з олеофільного емульгатора «Естер Твердий-2 (T-2)» та казеїнату натрію. Відповідно до методики дослідження визначали загальну кількість КМАФАнМ, дріжджів i пліснявих грибів та бактерій групи кишкової палички як показник мікробіологічної безпеки емульсій. За результатами дослідження встановлено, що показник КМАФАнМ усіх зразків одразу після отримання емульсії знаходиться на рівні 1,6...4,8 $10^{2} \mathrm{KУO/2} і$ на три порядки менший за нормативні вимоги (КМАФАнМ, КУО/2, не більше $\left.2 \cdot 10^{5}\right)$. Результати дослідження підтвердили безпечність емульсій впродовж технологічно доцільного зберігання перед внесенням до складу молоковмісних продуктів.

Ключові слова: харчова емульсія, казеїнат натрію, емульгатор, активність води, мікробіологічний аналіз.

Постановка проблеми. На сучасному етапі розвитку молочної промисловості спостерігається тенденція частково або повністю замінювати молочний жир на рослинні олії і замінники молочного жиру у вигляді емульсійних систем - харчових емульсій як аналогів вершків, які використовують для нормалізації молоковмісних продуктів $[1 ; 2]$.

Однією з вимог, що висуваються до харчових, зокрема молоковмісних продуктів, $є$ їх безпека для споживачів. Основна причина псування продуктів, що викликає харчові отруєння, обумовлюється наявністю у їх складі умовнопатогенних і санітарно-показових мікроорганізмів [3].

Кількість мікробних клітин і швидкість їх росту залежать від складу та властивостей сировини і напівфабрикатів, режимів їх попереднього оброблення, санітарно-гігієнічних умов виробництва й зберігання готового продукту. Своєчасне якісне і кількісне виявлення цих мікроорганізмів як критерію ефективності проведення теплового оброблення харчових систем емульсійного типу різного хімічного складу допомагає запобігати вказаним негативним явищам [4].

Для активного розвитку бактерій і дріжджів необхідна вільна волога, оскільки поживні речовини проникають у клітину тільки в розчиненому вигляді. У зв'язаній формі вода для них недоступна. Тобто існує залежність між станом води в продукті і розвитком мікроорганізмів у ньому. Тому актив- 
ність води (AB) у харчових продуктах є одним 3 найважливіших показників, який характеризує рівень життєдіяльності мікроорганізмів. Для кожного виду мікроорганізмів існують максимальне, мінімальне й оптимальне значення AВ. Відхилення значення АВ від оптимального призводить до гальмування процесів життєдіяльності мікроорганізмів, а іноді і до їх загибелі. АВ можна змінювати шляхом додавання речовин, які зв’ язують воду [5]. Тому до складу водної фази систем емульсійного типу доцільно вносити гідроколоїди (білки, полісахариди та ін.) та істинно розчинні низькомолекулярні сполуки (солі, моно- і дицукри та ін.) Використання білків у складі емульсій також обумовлено їхніми поліфункціональними технологічними властивостями. Зокрема, казеїнат натрію (КН) виявляє емульгуючу та стабілізуючу дію та має високу водо- і жирозв'язуючу властивість, структурує водну фазу [6-8].

Ризик мікробіологічного псування жирових емульсійних систем теоретично можна знижувати шляхом підвищення ступеня їх дисперсності. У процесі одержання емульсій необхідно приділяти велику увагу умовам, що забезпечують ефективне диспергування жирової фази, оскільки емульсії прямого і зворотного типів («масло-вода» та «вода-масло») з високим ступенем дисперсності (середні розміри жирових кульок, що не перевищують 2 мкм) мають більшу стійкість до мікроорганізмів. Це можна пояснити зменшенням розмірів прошарків водної фази, що оточує жирові кульки, або зменшенням вмісту води, необхідної для життєдіяльності мікроогранізмів [9;10].

Технологія харчової емульсії (аналогу молочних вершків), розроблена авторами, передбачає використання рослинних олій, купажів і замінника молочного жиру («Віолія-молжир 3»), олеофільного («Естер Твердий-2 (Т2)») та гідрофільного (казеїнат натрію) емульгаторів. Одержувані харчові емульсії характеризуються високими показниками якості: стійкість складає не менше $100 \%$, а середній розмір жирових кульок - не більший за 2 мкм. Отже, ці емульсії за фізичними характеристиками цілком відповідають вимогам, наведеним вище [11; 12].

Відповідно до розробленої технології, харчові емульсії передбачено отримувати шляхом гомогенізації молочно-жирових сумішей на гомогенізаторі-диспергаторі за температури не нижче $60^{\circ} \mathrm{C}$ і тиску не нижче 10 МПа. Згідно з ДСТУ 8131:2015 «Вершки-сировина Технічні умови», строк зберігання вершків, отриманих 3 молока шляхом сепарування за температури $40 \pm 5^{\circ} \mathrm{C}$ із моменту їх отримання до використання у технологіях молочних продуктів, становить 24 год при температурі не вище $4^{\circ} \mathrm{C}$. У той же час у ГОСТ Р 53435-2009 «Сливки-сырые. Технические условия» наведено вимоги до умов зберігання вершків, у тому числі пастеризованих - 48 год при температурі не вище $8^{\circ} \mathrm{C}$. Саме тому вказані умови зберігання пастеризованих вершків було прийнято за еталон для результатів експериментального визначення мікробіологічної чистоти харчових емульсій як рецептурного компонента у складі молоковмісних продуктів.

Мікробіологічні показники харчових емульсій відразу після отримання та впродовж технологічно доцільного тимчасового зберігання (до 48 год) мають гарантувати повну безпечність молоковмісних продуктів, до складу яких їх передбачено вносити. 
Метою дослідження $є$ підтвердження безпечності харчових емульсій, призначених для нормалізації молоковмісних продуктів і одержуваних за визначеними режимами емульгування.

Матеріали і методи. Об'єктами дослідження обрано зразки харчових емульсій з масовою часткою жиру 10\% (зразок № 1), 20\% (зразок № 2), $30 \%$ (зразок № 3), 40\% (зразок № 4) та 50\% (зразок № 5).

Харчові емульсій готували за розробленими авторами рецептурами (табл. 1).

Таблиця 1. Рецептури харчових емульсій різного хімічного складу

\begin{tabular}{|c|c|c|}
\hline $\begin{array}{c}\text { Масова частка емульгатора } \\
\text { Т-2, \% }\end{array}$ & $\begin{array}{c}\text { Масова частка КН } \\
\text { (в перерахунку на білок), \% }\end{array}$ & Масова частка води, \% \\
\hline \multicolumn{3}{|c|}{ Зразок № 1} \\
\hline $0,15-0,25$ & $5,0-6,0$ & $84,85-83,75$ \\
\hline \multicolumn{3}{|c|}{ Зразок № 2} \\
\hline $0,25-0,35$ & $4,0-5,0$ & $75,75-74,65$ \\
\hline \multicolumn{3}{|c|}{ Зразок № 3} \\
\hline $0,35-0,45$ & $3,0-4,0$ & $66,65-65,55$ \\
\hline \multicolumn{3}{|c|}{ Зразок № 4} \\
\hline $0,45-0,55$ & $2,0-3,0$ & $57,55-56,45$ \\
\hline \multicolumn{3}{|c|}{ Зразок № 5} \\
\hline $0,55-0,65$ & $1,0-2,0$ & $48,45-47,35$ \\
\hline
\end{tabular}

Зразки харчових емульсій на прикладі систем з кукурудзяною олією готували таким чином: олію попередньо підігрівали до температури не нижче $75^{\circ} \mathrm{C}$, вносили емульгатор «Естер Твердий-2 (Т-2)» та розчиняли його в олії впродовж 20 хвилин. Водний розчин білка отримували внесенням КН у питну воду за температури не нижче $76 \pm 2^{\circ} \mathrm{C}$ за постійного перемішування з витримуванням не менше 20 хвилин. Грубодисперсні емульсії одержували змішуванням жирової та водно-білкової фаз за постійного перемішування мішалкою пропелерного типу з частотою обертів 500 хв$^{-1}$ впродовж 5 хвилин. Одержану грубодисперсну молочно-жирову суміш гомогенізували при температурі 60$65^{\circ} \mathrm{C}$ за тиску не нижче 10,0 МПа на першому ступені і 2,5...3,0 МПа — на другому.

Для дослідження динаміки зміни показників мікробіологічної безпеки і стабільності харчових емульсій у процесі зберігання досліджувані зразки аналізували протягом 96 годон. Визначали такі групи мікроорганізмів: загальну кількість мезофільних аеробних і факультативно-анаеробних мікроорганізмів (кМАФАМ) згідно з ГОСТ 9225, бактерії групи кишкових паличок (коліформні бактерії) - згідно з ГОСТ 9225. Окрім вищеназваних мікробіологічних показників, відповідно до стандарту, перевіряли кількість дріжджів і пліснявих грибів згідно з ГОСТ 10444.12.

Дослідження активності води здійснювали на аналізаторі активності води «HygroLab 2» (Rotronic, Швейцарія) за температури $20^{\circ} \mathrm{C}$ в діапазоні вимірювання $0 \ldots 1$ Aw $(0 \ldots 100 \% \mathrm{rh})$.

Результати і обговорення. За результатами проведеного дослідження визначено мікробіологічні показники зразків харчових емульсій з різним 
вмістом жиру та активністю води. Мікробіологічні показники харчової емульсії з різною масовою часткою жиру наведено у табл. 2.

Таблиия 2. Мікробіологічні показники емульсій

\begin{tabular}{|c|c|c|c|c|c|c|c|}
\hline \multirow{3}{*}{$\begin{array}{l}\text { Номер } \\
\text { зразка }\end{array}$} & \multicolumn{5}{|c|}{ КМАФАнМ, КУО/Г } & \multirow{2}{*}{\begin{tabular}{|c} 
Дріжджі та \\
плісеневі \\
гриби, КУО/г
\end{tabular}} & \multirow[b]{2}{*}{ БГКП } \\
\hline & \multicolumn{5}{|c|}{ термін зберігання, год } & & \\
\hline & 0 & 24 & 48 & 72 & 96 & \multirow{6}{*}{$<30$} & \multirow{6}{*}{$\begin{array}{c}\text { Не } \\
\text { виявлено } \\
\text { у } 0,01 \Gamma\end{array}$} \\
\hline 1 & $1,6 \cdot 10^{2}$ & $1,7 \cdot 10^{3}$ & $3,8 \cdot 10^{3}$ & $4,8 \cdot 10^{3}$ & $5 \cdot 10^{3}$ & & \\
\hline 2 & $2,1 \cdot 10^{2}$ & $2 \cdot 10^{3}$ & $4,1 \cdot 10^{3}$ & $5 \cdot 10^{3}$ & $5,4 \cdot 10^{3}$ & & \\
\hline 3 & $2,7 \cdot 10^{2}$ & $2,4 \cdot 10^{3}$ & $4,1 \cdot 10^{3}$ & $5,4 \cdot 10^{3}$ & $5,8 \cdot 10^{3}$ & & \\
\hline 4 & $3,2 \cdot 10^{2}$ & $3,1 \cdot 10^{3}$ & $4,5 \cdot 10^{3}$ & $5,6 \cdot 10^{3}$ & $6,1 \cdot 10^{3}$ & & \\
\hline 5 & $4,8 \cdot 10^{2}$ & $3,2 \cdot 10^{3}$ & $3,9 \cdot 10^{3}$ & $4,1 \cdot 10^{3}$ & $6,3 \cdot 10^{3}$ & & \\
\hline
\end{tabular}

Показник КМАФАнМ усіх зразків одразу після отримання емульсій знаходився на рівні $1,6-4,8 \cdot 10^{2} \mathrm{KУО} /$, що практично на три порядки менше за нормативні значення (КМАФАнМ, КУО/г, не більше $2 \cdot 10^{5}$ ). Варто зазначити, що нормативні вимоги до такого роду сировини поки що не розроблено, тому результати порівнювали з нормативами, зазначеними в ДСТУ 8131:2015 «Вершки-сировина Технічні умови».

Крім того, у досліджених зразках БГКП не виявлено в 0,01 г, а кількість спор пліснявих грибів і дріжджів є меншою за 30 КУО/г, що свідчить про суттєвий антимікробний вплив температурних умов приготування та гомогенізації емульсій.

Відразу після отримання емульсії характеризувалися певним вмістом мікробіоти. Слід зазначити, що емульсії з вищим вмістом жиру більш обнасінені мікроогранізмами, що можна пояснити впливом жирової фази в якості захисного бар'єру внаслідок іiі меншої теплопровідності, порівняно з водною фазою, в результаті чого більша кількість клітин спроможна витримувати температурні умови гомогенізації.

Після приготування, отримані зразки зберігали у холодильній камері за температури $4 \pm 2{ }^{\circ} \mathrm{C}$. Показник КМАФАнМ, а також кількість спор пліснявих грибів і дріжджів у всіх пробах перевіряли через 24, 48, 72 та 96 год зберігання. Встановлено, що значення показників КМАФАМ харчової емульciï протягом 96 год зберігання були нижчими за встановлені стандартом норми і знаходились на рівні не вище ніж $6,3 \cdot 10^{3}$, тобто майже на два порядки менші за нормативні показники. Відповідно до одержаних результатів дослідження строк зберігання емульсії може бути збільшений, хоча зазвичай технологічно доцільна тривалість тимчасового резервування не перевищує 24...48 год. Такий позитивний вплив, на наш погляд, $є$ результатом достатньо ефективного теплового оброблення за додаткового зв'язування вільної води КН, що впливає на показник АВ.

Для підтвердження вказаного вище припущення досліджували зміну показника АВ водної фази емульсій з різним вмістом КН, що відповідає рецептурному складу жирових систем за вмісту жиру від 10 до 50\%. Масова частка КН у перерахунку на білок у водній фазі емульсій з різним вмістом жиру та відповідні значення показника АВ представлені у табл. 3. 
Таблиця 3. Показник активності води у водній фазі емульсій за різного вмісту казеїнату натрію $(P \geq 0,95 ; n=3)$

\begin{tabular}{|c|c|c|}
\hline $\begin{array}{c}\text { Масова частка жиру } \\
\text { харчової емульсії, \% }\end{array}$ & Вміст КН у водній фазі,\% & Показник активності води, aw \\
\hline 10 & 7,2 & $0,982 \pm 0,015$ \\
\hline 20 & 6,3 & $0,986 \pm 0,014$ \\
\hline 30 & 5,6 & $0,990 \pm 0,015$ \\
\hline 40 & 4,4 & $0,991 \pm 0,017$ \\
\hline 50 & 3,5 & $0,993 \pm 0,020$ \\
\hline
\end{tabular}

Відповідно до отриманих даних встановлено, що за збільшення масової частки КН у водній фазі від 3,5 до 7,2 \% значення АВ дещо знижується (на $0,011 \mathrm{aw})$ в межах похибки вимірювання. Тому підтверджено, що КН не $\epsilon$ сполукою, спроможною суттєво впливати на значення показника АВ.

Отже, результати дослідження свідчать про те, що саме передбачені в технологічній схемі температурні режими забезпечують мікробіологічну чистоту жирового напівфабрикату і можуть бути рекомендовані в технологічних схемах одержання молоковмісних продуктів.

Перспектива подальших досліджень полягає в дослідженні мікробіологічних показників молоковмісних продуктів, що нормалізовані харчовими емульсіями гарантованої якості з різним хімічним складом.

\section{Висновки}

1. Усі зразки харчових емульсій з масовою часткою жиру від 10 до $50 \%$ відповідають нормативним вимогам за мікробіологічною чистотою і можуть гарантовано зберігатися впродовж $24 . . .48$ год за температури $4 \pm 2{ }^{\circ} \mathrm{C}$.

2. Встановлено, що за збільшення вмісту жиру в харчових емульсіях підвищується показник КМАФАМ, що пояснюється захисною дією жирової фази стосовно мікроорганізмів під час теплового оброблення.

3. Результати дослідження підтверджують мікробіологічну безпечність харчових емульсій прямого типу в широкому діапазоні вмісту жиру у разі їх подальшого використання в складі молоковмісних продуктів.

\section{Література}

1. Голубева Л.В. Влияние немолочных жиров на качество новых молокосодержащих продуктов / Л.В. Голубева, О.И. Долматова, О.Б. Стремилова, Е.И. Бочарова // Хранение и переработка сельхозсырья. - 2012- № 4. - С. 49-50.

2. Попова Н.В. Удосконалення рецептури збагачених глазурованих сирків з начинкою / Н.В. Попова, В.В. Ткаченко // Наукові праці Національного університету харчових технологій. - 2016. - № 3. - С. $224-230$.

3. Beal C. Comparison of growth, acidification and productivity of pure and mixed cultures of Streptococcus salivarius ssp. Thermophilus 404 and Lactobacillus delbreuckii ssp. Bulgaricus 398 / C. Beal, N.Spinnler, G. Carrieu // Applied Microbiology and Bacteriology. - 1994. Vol.41, № 1. - P. 95-98.

4. Грегірчак Н.М. Мікробіологічний аналіз вершкових кремів пониженої жирності/ Н.М. Грегірчак, О. О. Українець, Ю.П. Звягінцева-Семенець, О.В. Кобилінська, Ю.В. Камбулова // Наукові праці Національного університету харчових технологій. - 2017. T. 23, № 3. - C. $238-245$. 
5. Maltini E. Water activity and the preservation of plant foods / E. Maltini, D. Torreggiani, E. Venir, G. Bertolo // Food Chem. - 2003. — \# 82. - P 79-86.

6. Surh $J$. Influence of $\mathrm{pH}$ and pectin type on properties and stability of sodium-caseinatestabilized oil-in-water emulsions/ J. Surh, E.A. Decker, D.J. McClements // Food Hydrocolloids. - 2006. - \# 5. - P. 607-618

7. Eastoc J., Surfactant aggregation and adsorption at interfaces. In: Cosgrove. T. (ed) / J. Eastoc // Colloid Science: Principles, Methods and Applications, Blackwell. Ames. — 2005. Vol.1. - P. 50-76.

8 McCarthy DJ. Milk: Physical and physics. Chemical properties. In: H. Roginski. JW Fuquay. PF Fox (Eds). Encyclopedia of Dairy Sciences. Academic Press, New York. - 2003. P. 1812-1821.

9. Давидова О.Ю. Розробка технології соусів 3 кісточкових плодів : дис. ... кандидата техн. наук : 05.18.16 / О.Ю. Давидова. - Харків, 2001. - 160 с.

10. Рашевська T.О. Мікробіологічні дослідження вершкового масла з кріопорошком із буряка червоного столового / Т.О. Рашевська // Збірник наукових праць Харківської державної академії технології та організації харчування. - 2001. - С. $20-22$.

11. Полішук Г. Научное обоснование состава эмульсий для нормализации белковожировых продуктов / Г. Полищук, Г. Симахина, И. Устименко и др. // Maisto chemija ir technologija. Mokslo darbai. — 2016. - T. 50, № 1.-P. 45-55.

12. Патент на КМ. 112302 Україна, МПК А23С 11/00/ Поліщук Г.С., Бондарчук О.О., Устименко І.М.,заявник і патентовласник НУХТ. — № u201606330 ; заявл. 10.06.2016 ; опубл. 12.12.2016, Бюл. № 23. 